DOI: $10.2478 / \mathrm{v} 10025-012-0009-9$

JOURNAL OF WATER

AND LAND DEVELOPMENT

J. Water Land Dev. No. 15, 2011: 91-98

\title{
Assessing the factors limiting the Rosa gallica L. shrub occurrence in Romanian grasslands (case study)
}

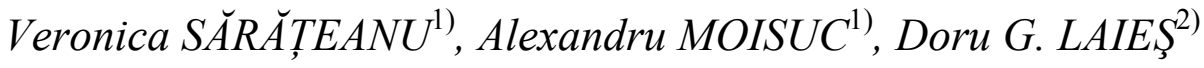 \\ 1) Banat's University of Agricultural Sciences and Veterinary Medicine, Calea Aradului 119, 300645 \\ Timişoara, Romania; e-mail: vera_s_vera@yahoo.com \\ 2) Bardeau Holding, Grădinari, Caraş-Severin County, Romania
}

\begin{abstract}
The purpose of this work is to show how are influencing different fertilisation types and years of utilisation on the occurrence of the species Rosa gallica L. (French rose) in the analysed grassland. Other aspects analysed here are its interrelation with different parameters of the vegetation as botanical composition, biodiversity and pastoral value. The vegetation data were collected using the linear point-quadrate method. The analysed permanent grassland has a relatively constant contribution of the species $R$. gallica $\mathrm{L}$. in the vegetation sward. The grassland where it was developed this study was dominated by Festuca valesiaca Schleich. ex Gaudin and Filipendula vulgaris Moench., other species with important contributions being Achillea millefolium L., Plantago lanceolata L. and $R$. gallica $L$. The fertilisation and harvesting of the biomass hasn't influenced the contribution of $R$. gallica $\mathrm{L}$. during the six years of researches.
\end{abstract}

Key words: fertilisation, floristic composition, grassland, Rosa gallica L., vegetation

\section{INTRODUCTION}

Rosa gallica L. is a moderate thermophilic low growing (DúBRAVKOVÁ et al., 2010) shrub species commonly found in Europe, Asia Minor and North Africa from lowland to highland. In Romania it can be found in very different habitats as pastures and hayfields, cultivated land, shrubland, sunny slopes, forest edge and meadows (PÂRVU, 2000). In other countries, as Poland French rose is a rare and endangered species (TOWPASZ and CWENER, 2002). $R$. gallica L. is a representative of the steppe-scrubs that is forming dense thickets together with Prunus tenella Batsch, P. fruticosa Pall. and R. spinosissima L. (BAUER, 2009).

Other literature sources are considering $R$. gallica L. as grassland weed, respectively undesirable elements (KOJIČ et al., 2001), while in United States is considered as non-indigenous naturalised species with invasive potential (AMRINE, 2002). The purpose of this work is to show how are influencing different fertilisa- 
tion types and years of utilisation on the occurrence of the species Rosa gallica L. (French rose) in the analysed grassland.

\section{MATERIAL AND METHODS}

The field experiences were carried out during 2004-2009 on permanent grassland from Grădinari (Caraş-Severin County, western Romania). The analysed grassland belongs to the forest steppe type, the soil being brown alluvial type; the plots were harvested biannually, the biomass being removed from the plots. The average yearly air temperature is $10.9^{\circ} \mathrm{C}$, the yearly average rainfall amount is 836 $\mathrm{mm}$ and the altitude $195 \mathrm{~m}$ a.s.l. There were applied 9 fertilisation variants and one control (V1) in three replicates. The fertilisation types were the following: natural fertiliser $\left(20 \mathrm{t} \cdot \mathrm{ha}^{-1}\right.$ manure $-\mathrm{V} 2,40 \mathrm{t} \cdot \mathrm{ha}^{-1}$ manure $-\mathrm{V} 3,60 \mathrm{t} \cdot \mathrm{ha}^{-1}$ manure $\left.-\mathrm{V} 4\right)$, mixed (20 th ha ${ }^{-1}$ manure $+\mathrm{P}_{50}-\mathrm{V} 5 ; 20 \mathrm{t} \cdot \mathrm{ha}^{-1}$ manure $+\mathrm{P}_{50}+\mathrm{K}_{50}-\mathrm{V} 6 ; 20 \mathrm{t} \cdot \mathrm{ha}^{-1}$ manure $\left.+\mathrm{N}_{50}+\mathrm{P}_{50}+\mathrm{K}_{50}-\mathrm{V} 7\right)$ and mineral $\left(\mathrm{N}_{100}+\mathrm{P}_{50}+\mathrm{K}_{50}-\mathrm{V} 8 ;+\mathrm{N}_{150}+\mathrm{P}_{50}+\right.$ $\left.\mathrm{K}_{50}-\mathrm{V} 9 ; \mathrm{N}_{150+100}+\mathrm{P}_{50}+\mathrm{K}_{50}-\mathrm{V} 10\right)$. The manure was applied once in two years and the mineral fertilisers every year. The vegetation data were collected using the linear quadrat point method (DAGET and POISSONET, 1971). The vegetation parameters analysed were: number of grasses, legumes and other species number, contribution $(S C \%)$ of grasses, legumes and other species, Shannon index $\left(H^{\prime}\right)$, Simpson index $(D)$ and pastoral value $(V P)$ on $0-100$ scale. The specific contribution $(S C \%)$ was calculated considering the number of contacts and represents the report between the specific frequency of a given species and the total of the specific frequencies of the taxa from the relevé using the following formula:

$$
C S_{i} \%=\left(F S_{i} / \Sigma F S_{i}\right) 100
$$

where:

$F S_{i} \quad-$ specific frequency of the species $i$;

$\Sigma F S_{i}$ - the sum of the specific frequencies of the taxons from a relevé (DAGET and POISSONET, 1971).

Shannon's entropy and Simpson index are used for the estimation of the biodiversity.

Shannon's entropy $H^{\prime}$ is calculated using the formula:

$$
H^{\prime}=-\sum_{i=1}^{S} p_{i} \ln p_{i}
$$

where:

$S$ - species number from the analysed sample (species richness);

$p_{i}$ - proportion of $i$ species from $S$, respectively $n_{i}: N$ (BEALS et al., 2000). 
Simpson's index $D$ was calculated using the next formula:

$$
D=\sum\left(n_{i} / N\right)^{2}=\sum_{i=1}^{S} p_{i}^{2}
$$

where:

$n_{i}-$ total individual number of the species $i$;

$N$ - total number of the individual of the species from the sample (BEALS et al., 1999).

The pastoral value $V P$ was calculated after the following formula:

$$
V P=0.2 \Sigma\left(C S_{i} I S_{i}\right)
$$

where:

$C S_{i}-$ specific contribution of the species $i$;

$I S_{i}$ - specific quality index of the species $i$ (DAGET and POISSONET, 1971).

The statistical methods used are ANOVA, linear regression and Pearson's correlation coefficient $r$.

\section{RESULTS AND DISCUSSION}

At the beginning of the study the analysed grassland is dominated by the species Festuca valesiaca Schleich. ex Gaudin. Other species with important contribution in the sward are Filipendula vulgaris Moench, Achillea millefolium L., Plantago lanceolata L., Briza media L., Lotus corniculatus L., Lathyrus pratensis L., Lathyrus nissolia L., Hieracium pilosella L., R. gallica L. shrub is present in all the plots of the grassland analysed here and persists in the vegetation cover instead of the biomass harvesting twice a year.

Analysing the influence of fertilisation doses applied on the contribution of Rosa gallica L. the results obtained show that it isn't any difference of the $R$. gallica L. contribution among the fertilisation doses (Tab. 1); this aspect being evidenced by the $p$ value (0.999) that is greater than the significance level $(0.01)$.

Table 1. ANOVA results for the contribution of Rosa gallica at different fertilization doses

\begin{tabular}{l|c|r|c|c|c|c}
\hline Source of variation & $S S$ & $d f$ & $M S$ & $F$ & $P$-value & $F$ crit \\
\hline Between fertilisation variants & 1.301407 & 9 & 0.144601 & 0.106884 & 0.999394 & 2.784956 \\
Within fertilisation variants & 67.64387 & 50 & 1.352877 & & & \\
Total & 68.94527 & 59 & & & & \\
\hline
\end{tabular}


Other factor analysed here for the influence on the $S C \%$ of $R$. gallica $\mathrm{L}$. is the number of years of biomass harvesting, the single factor ANOVA results being represented in Table 2 . The repeated harvesting of the biomass isn't influencing the $S C \%$ of $R$. gallica L. in grassland ( $p>0.01)$.

Table 2. ANOVA results for the contribution of Rosa gallica for different number of years of biomass harvesting

\begin{tabular}{l|c|c|c|c|c|c}
\hline Source of Variation & $S S$ & $d f$ & $M S$ & $F$ & $P$-value & $F$ crit \\
\hline Between harvesting years & 14.94717 & 5 & 2.989435 & 2.98954 & 0.018728 & 3.376912 \\
Within harvesting years & 53.99810 & 54 & 0.999965 & & & \\
Total & 68.94527 & 59 & & & & \\
\hline
\end{tabular}

Analysing the correlations between $R$. gallica and several vegetation parameters (Fig. 1) as number of grasses, legumes and other species number, contribution of grasses, legumes and other species, $H^{\prime}, D$ and $V P$ the obtained values shown the absence of the interrelation except the biodiversity indexes $\left(H^{\prime}\right.$ and $\left.D\right)$ and the number of other species that were expressing a weak relationship, which is possible to be influenced by other factors too.

In Table 3 were presented some aspects of the floristic composition of the analysed sward.

The lowest $S C \%$ of the grasses was determined in 2006 in V4 (17.08\%) and V3 (17.5\%) and the highest in 2005 in V10 (82.93\%). Mineral fertilisation was determining a greater contribution of the grasses and the manure applies lower. In the case of legumes there was determined the absence of these species in 2007 in V6 $(0 \%)$, and the greatest value was found in 2003 in V3 (61.24\%) and V2 (60\%). Natural fertilisation was generally determining the increase of the legumes contribution in the vegetation cover. Regarding the contribution of the species from other families the lowest value was determined in 2005 in V10 (11.24\%) and the greatest in 2006 in V8 (60\%) and in 2008 in V5 (59.58\%).

\section{CONCLUSIONS}

French rose is a shrub species that in the case of the absence of the grassland use can become a problem by diminishing the useful surface. The fertilisation hasn't any influence on the spreading of this shrub in the grassland sward. When the biomass is harvested by cutting it is maintaining itself a relatively constant low contribution in the vegetation cover independent by fertilisation, this fact deriving from the statistical analysis of the data. According with this result, it is recommended the cutting of the unconsumed plants in the grazed grasslands with $R$. gallica after the ending of a grazing cycle to prevent the encroachment of this shrub. 

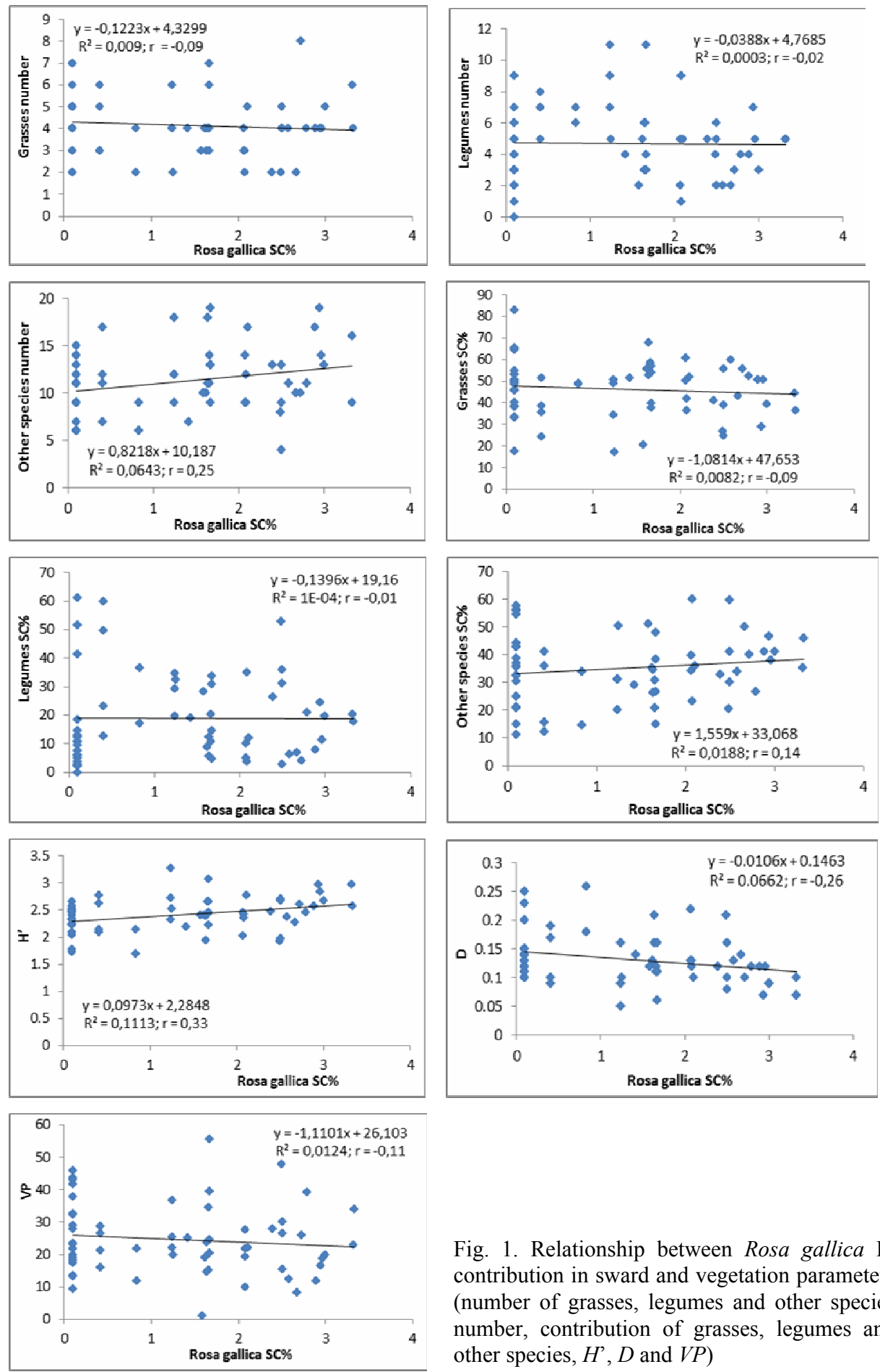

Fig. 1. Relationship between Rosa gallica L. contribution in sward and vegetation parameters (number of grasses, legumes and other species number, contribution of grasses, legumes and other species, $H^{\prime}, D$ and $V P$ ) 
Table 3. Aspects of the floristic composition of the grassland depending on fertilisation variants

\begin{tabular}{|c|c|c|c|c|c|c|c|c|c|c|c|c|}
\hline \multirow{3}{*}{ 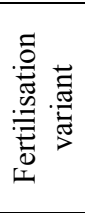 } & \multicolumn{12}{|c|}{ Year } \\
\hline & \multicolumn{2}{|c|}{2004} & \multicolumn{2}{|c|}{2005} & \multicolumn{2}{|c|}{2006} & \multicolumn{2}{|c|}{2007} & \multicolumn{2}{|c|}{2008} & \multicolumn{2}{|c|}{2009} \\
\hline & $\begin{array}{l}\text { spe- } \\
\text { cies } \\
\text { no. }\end{array}$ & $S C \%$ & $\begin{array}{l}\text { spe- } \\
\text { cies } \\
\text { no. }\end{array}$ & $S C \%$ & $\begin{array}{l}\text { spe- } \\
\text { cies } \\
\text { no. }\end{array}$ & $S C \%$ & $\begin{array}{l}\text { spe- } \\
\text { cies } \\
\text { no. }\end{array}$ & $S C \%$ & $\begin{array}{l}\text { spe- } \\
\text { cies } \\
\text { no. }\end{array}$ & $S C \%$ & $\begin{array}{l}\text { spe- } \\
\text { cies } \\
\text { no. }\end{array}$ & $S C \%$ \\
\hline \multicolumn{13}{|c|}{ Grasses } \\
\hline V1 & 3 & 50.42 & 4 & 51.68 & 4 & 49.18 & 3 & 35.42 & 6 & 34.16 & 4 & 52.91 \\
\hline V2 & 3 & 50.00 & 3 & 24.17 & 5 & 51.66 & 4 & 58.74 & 4 & 39.59 & 4 & 28.84 \\
\hline V3 & 6 & 65.41 & 5 & 17.50 & 2 & 40.83 & 4 & 52.49 & 4 & 58.34 & 4 & 53.33 \\
\hline V4 & 7 & 46.22 & 2 & 26.67 & 2 & 17.08 & 3 & 48.75 & 4 & 50.64 & 4 & 36.24 \\
\hline V5 & 5 & 64.66 & 5 & 37.90 & 4 & 60.00 & 4 & 55.83 & 4 & 24.58 & 2 & 32.91 \\
\hline V6 & 4 & 50.82 & 4 & 48.75 & 2 & 38.34 & 4 & 45.43 & 5 & 39.17 & 3 & 41.66 \\
\hline V7 & 5 & 50.75 & 5 & 33.34 & 2 & 42.92 & 3 & 67.92 & 5 & 38.74 & 3 & 37.51 \\
\hline V8 & 7 & 65.40 & 6 & 38.32 & 2 & 36.25 & 4 & 50.83 & 6 & 44.18 & 2 & 49.17 \\
\hline V9 & 6 & 57.08 & 7 & 54.15 & 4 & 49.51 & 4 & 60.83 & 5 & 52.09 & 5 & 53.33 \\
\hline V10 & 5 & 40.00 & 4 & 82.93 & 3 & 20.41 & 4 & 55.84 & 8 & 55.82 & 5 & 54.99 \\
\hline \multicolumn{13}{|c|}{ Legumes } \\
\hline V1 & 5 & 10.00 & 4 & 19.17 & 7 & 19.57 & 8 & 23.33 & 11 & 34.58 & 6 & 12.49 \\
\hline $\mathrm{V} 2$ & 3 & 12.91 & 7 & 60.00 & 5 & 12.51 & 6 & 20.42 & 11 & 33.67 & 7 & 24.57 \\
\hline V3 & 4 & 2.07 & 9 & 61.24 & 5 & 26.25 & 4 & 20.83 & 6 & 10.84 & 5 & 10.83 \\
\hline V4 & 6 & 18.33 & 4 & 52.92 & 5 & 32.50 & 3 & 12.50 & 9 & 29.17 & 5 & 17.92 \\
\hline V5 & 3 & 2.92 & 5 & 41.25 & 2 & 6.25 & 5 & 8.75 & 5 & 35.84 & 5 & 10.83 \\
\hline V6 & 5 & 11.25 & 6 & 36.65 & 2 & 5.83 & 0 & 0.00 & 3 & 19.58 & 9 & 35.00 \\
\hline V7 & 4 & 5.00 & 6 & 51.65 & 2 & 7.08 & 3 & 5.72 & 6 & 31.25 & 4 & 14.58 \\
\hline V8 & 7 & 9.58 & 7 & 49.59 & 1 & 3.75 & 4 & 7.91 & 5 & 20.42 & 7 & 17.08 \\
\hline V9 & 3 & 4.58 & 3 & 30.83 & 2 & 7.50 & 2 & 5.00 & 5 & 12.09 & 3 & 3.75 \\
\hline V10 & 3 & 2.50 & 1 & 5.83 & 2 & 28.33 & 2 & 2.91 & 3 & 4.16 & 3 & 14.58 \\
\hline \multicolumn{13}{|c|}{ Other families } \\
\hline V1 & 9 & 39.58 & 7 & 29.15 & 9 & 31.25 & 17 & 41.25 & 18 & 31.26 & 18 & 34.60 \\
\hline V2 & 6 & 37.09 & 7 & 15.83 & 12 & 35.83 & 11 & 20.84 & 19 & 26.74 & 19 & 46.59 \\
\hline V3 & 11 & 32.52 & 9 & 21.26 & 13 & 32.92 & 11 & 26.68 & 14 & 30.82 & 11 & 35.84 \\
\hline V4 & 14 & 35.45 & 8 & 20.41 & 12 & 50.42 & 11 & 38.75 & 12 & 20.19 & 9 & 45.84 \\
\hline V5 & 15 & 32.42 & 6 & 20.85 & 11 & 33.75 & 10 & 35.42 & 9 & 59.58 & 9 & 56.26 \\
\hline V6 & 14 & 37.92 & 9 & 14.6 & 11 & 55.83 & 9 & 54.57 & 13 & 41.25 & 9 & 23.34 \\
\hline V7 & 14 & 44.25 & 6 & 15.01 & 10 & 50.00 & 11 & 26.36 & 13 & 30.01 & 13 & 47.91 \\
\hline V8 & 12 & 25.02 & 11 & 12.09 & 12 & 60.00 & 17 & 41.26 & 16 & 35.40 & 6 & 33.75 \\
\hline V9 & 13 & 38.34 & 9 & 15.02 & 7 & 42.99 & 14 & 34.17 & 17 & 35.82 & 13 & 42.92 \\
\hline V10 & 9 & 57.50 & 6 & 11.24 & 10 & 51.26 & 4 & 41.25 & 10 & 40.02 & 12 & 30.43 \\
\hline
\end{tabular}




\section{ACKNOWLEDGEMENTS}

This work was published during the project "Postdoctoral School of Agriculture and Veterinary Medicine", POSDRU/89/1.5/S/62371, co-financed by the European Social Fund through the Sectorial Operational Programme for the Human Resources Development 2007-2013.

\section{REFERENCES}

1. AmRine J.W. Jr., 2002. Multiflora rose. In: Control of Invasive Plants in the Eastern United States. Eds F.V. Driesche, B. Blossey, M. Hoodle, S. Lyon, R. Reardon. Biological United States Department of Agriculture Forest Service. Forest Health Technology Enterprise Team. Morgantown, West Virginia. FHTET-2002-04: 1-413.

2. BAUER N., 2009. Vegetation of the Baglyas-Iszka-Hegy dolomite horst range (Bakony MTS, Hungary). Studia Botanica Hungarica, 40: 11-35.

3. Beals M., Gross L., Harrell S., 2000. Diversity indices: Shannon's H and E. The Institute for Environmental Modelling (TIEM), University of Tennessee, USA.

4. Daget P., Poissonet J., 1971. Une méthode d'analyse phytologique des prairies. Critéres d'application. Annales Agronomiques, 22(1): 5-41.

5. Dúbravková D., Chytrý M.,Willner W., Illyés E., JanišovÁ M., Kállayné Szerényi J., 2010. Dry grasslands in the Western Carpathians and the northern Pannonian Basin: a numerical classification. Preslia, 82: 165-221.

6. KoJiČ M., VRbničAnin S., DAJIĆ Z., Mrfat-Vukelić S., 2001. Weed flora of natural grasslands in Serbia. Acta Herbologica, 10 (1): 1-22.

7. PÂRVU C., 2000. Universul plantelor - Mică enciclopedie. Editura Enciclopedică Bucure ti: $1-872$.

8. TOWPasz K., Cwener A., 2002. Występowanie Rosa gallica (Rosaceae) na Płaskowyżu Proszowickim (Wyżyna Małopolska, południowa Polska). (Occurrence of Rosa gallica (Rosaceae) on the Proszowice Plateau (Małopolska Upland, South Poland)). Fragmenta Floristica et Geobotanica Polonica, 9 (9): 115-125.

\section{STRESZCZENIE}

\section{Ocena czynników ograniczających występowanie Rosa gallica L. na użytkach zielonych Rumunii}

Słowa kluczowe: nawożenie, skład florystyczny, użytek zielony, Rosa gallica L., roślinność

Celem przedstawionej pracy było wykazanie, w jaki sposób nawożenie i czas użytkowania wpływają na występowanie Rosa gallica L. na badanych użytkach zielonych. Badano także wpływ innych czynników, jak: skład botaniczny, różnorodność gatunkowa i wartość pastewna. Dane o roślinności zbierano metodą punktowo-kwadratowa. Udział $R$. gallica L. w runi badanego trwałego użytku zielonego był w miarę stały. Dominującymi gatunkami były tam Festuca valesiaca Schleich. ex Gaudin i Filipendula vulgaris Moench., a znaczny udział w runi miały także 
Achillea millefolium L., Plantago lanceolata L. i R. gallica L. Nawożenie i zbiór biomasy nie wpływały na występowanie $R$. gallica L. w czasie 6 lat badań.

Received 28.07.2011 